\title{
Improvement of Durum Wheat (Triticum durum) Surface Irrigation in Swelling Soils
}

\author{
Adel Slatni ${ }^{1}$, Khemaies Zayani ${ }^{2}$, Ali Chebil ${ }^{1}$, Abdelaziz Zairi ${ }^{1}$, Samir Yacoubi $^{1}$, Enrique Playan $^{3}$ \\ ${ }^{1}$ National Institute of Research on Rural Engineering Water and Forestry (INRGREF), Carthage University, Tunis, Tunisia \\ ${ }^{2}$ High Institute of Environmental Sciences and Technology, Carthage University, Hammam Lif, Tunisia \\ ${ }^{3}$ Department of Soil and Water, Estación Experimental de Aula Dei, Consejo Superior de Investigaciones Científicas, \\ Zaragoza, Spain \\ Email: slatni.adel@iresa.agrinet.tn, khemaies.zayani@isste.rnu.tn, chebil.ali@iresa.agrinet.tn, zairi.abdelaziz@iresa.agrinet.tn, \\ yacoubi.samir@iresa.agrinet.tn, enrique.playan@csic.es
}

Received November 22, 2012; revised December 23, 2012; accepted January 10, 2013

\begin{abstract}
This study is targeted to improve surface irrigation performance of durum wheat in swelling soils. For this purpose, furrow and border irrigation trials were carried out and evaluated under different soil water depletion rates, furrow spacing and unitary inlet discharges. Irrigation was triggered whenever the soil water depletion rate reached a predetermined threshold. A comprehensive irrigation evaluation produced hydraulic, agronomic and economic indicators, such as application efficiency, distribution uniformity, crop yield, gross margin and water productivity. Experimental results showed that supplied water depths exceeded soil water deficits, inducing relevant vertical and lateral water losses. Although border and furrow irrigation crop yields were virtually tantamount (about $5.5 \mathrm{Mg} /$ ha), furrow irrigation was the system of choice. An irrigation strategy based on a furrow spacing of $150 \mathrm{~cm}$, an inlet discharge of $2 \mathrm{l} / \mathrm{s} / \mathrm{furrow}$ and a soil water depletion rate of $30 \%$ required a gross water depth of $4300 \mathrm{~m}^{3} / \mathrm{ha} / \mathrm{yr}$ and generated an optimum crop yield of $58 \mathrm{qx} / \mathrm{ha}$. In the analyzed range of soil water depletion, the gross margin and water value amounted to 1064 - $1390 \mathrm{Tu}-$ nisian Dinar per hectare (TD/ha) and $0.39-0.44 \mathrm{TD} / \mathrm{m}^{3}$, respectively, for a furrow spacing of $150 \mathrm{~cm}$.
\end{abstract}

Keywords: Irrigation; Borders; Furrows; Cracks; Soil Water Depletion Rate; Wheat; Irrigation Performance; Economic Analysis

\section{Introduction}

Water requirements of irrigated areas are endlessly growing because of irrigation intensification and the concomitant expansion of irrigated acreages. Given the acute competition between the different sectors (agriculture, industry, tourism, water drinking, ecological needs), water conservation is becoming a must [1]. Acreages served by surface irrigation have witnessed a noticeable worldwide regression during the last decade. This decline is likely ascribed to the low application efficiency of surface irrigation systems [2]. In California, Orang et al. [3] reported that surface irrigation was practiced on $50 \%$ of irrigated area in 2001 against $80 \%$ in the 1970's. Notwithstanding this decrease, surface irrigation remains widespread in California, particularly with field crops $(80 \%)$ and vegetables (43\%). At the aftermath of efforts to modernize irrigation in Spain, the area served by surface irrigation has dropped to $37 \%$ of the total irrigated area [4]. Despite public subsidies to curb excessive water use, surface irrigation is still practiced on more than 54\% of irrigated area in Tunisia. Aquastat [5] argues that about $25 \%$ of the area covered by surface irrigation in
Tunisia uses modernized techniques. It should be underlined that irrigation reengineering is facing several technical and socio-economic constraints. Improper surface irrigation strategies on cracked soils are synonymous of noteworthy water and nutrients losses. These are generated by the so-called bypass or funnel flow which results in a preferential flow within cracks [6]. It should be emphasized that cracks may result from the use of plowing tools, earthworms and processes such as swelling and shrinkage [7]. Moreover, vertisols are renowned by swelling and shrinkage phenomena during the sorption and desorption phases. Donahue et al. [8] estimated the area covered by vertisols to $1.8 \%$ of the world area. In these soils, the change of volume in the vertical direction induces the subsidence phenomenon, whereas the change of volume in the lateral direction causes the formation of cracks [9]. According to Cabidoche and Ney [10], vertisols are composed of smectite clay which may generate a suffocating environment compromising crop yields. Liu et al. [11] asserted that the applied water depth depends on the size of the cracks, but this interrelatedness is not lasting because of cracks' clogging. According to these 
authors, the infiltration flow rate is halved after 200 minutes of rainfall. It should be stressed that border irrigation in swelling soils causes a rapid closure of cracks and generates a virtually linear wave-front advance $10 \mathrm{~min}$ after the irrigation onset [12]. Under these circumstances, the humidification front is 3 to 10 times deeper than that of cracks. Considering water shortages, irrigation of cereals and fodder crops is often deficient in Tunisia. The triggering of irrigation often occurs at advanced stages of soil water deficit, leading to a significant depletion of soil water. It should be stressed that it is strenuous to tame surface irrigation and monitor it in cracked soils even with significant inlet discharges.

Studies carried out in Tunisia showed that a water supply of $200 \mathrm{~mm}$ often guarantees an average crop yield (Ya) up to 50 qx/ha every two years. Such a crop yield is deemed economically acceptable in arid areas [13]. The aforementioned water amount is commonly split between the sowing and flowering periods. Zairi et al. [14] showed that border irrigation in cracked clay-textured soils requires water supplies larger than $200 \mathrm{~mm}$ without achieving acceptable application efficiencies. This is particularly true for dense crops such as cereals and fodders. It should be emphasized that the previous assertion remains plausible as long as the irrigation interval is long. Clemmens and Dedrick [15] claimed that irrigation performance is often more related to on-farm water management than to the irrigation system itself. The performance of surface irrigation depends on soil infiltration, soil heterogeneity, land leveling, border or furrow length, field slope and inlet discharge $[16,17]$. Ignoring this would lead to excessive water intake and ipso facto to relevant water losses. The present study is devoted to the comprehensive evaluation of surface irrigation performance in cracked soils. The main objective is to seek for the optimal combination of relevant parameters which ascertains wise water conservation and acceptable durum wheat production.

\section{Material and Methods}

\subsection{Experimental Site}

Irrigation trials were carried out at the experimental station of INRGREF at Hindi Zitoun station. The latter is characterized by a lower semi-arid bioclimate. Rainfall episodes are sporadic and the mean inter-annual precipitation is quite small $(330 \mathrm{~mm})$. The soil texture is clayloamy. The water contents at field capacity and permanent wilting point, measured by Richards' pressure plates are 0.306 and $0.149 \mathrm{~g} / \mathrm{g}$, respectively. Inasmuch as the soil is homogeneous and deep, these values produce a water holding capacity of $230 \mathrm{~mm} / \mathrm{m}$. The zone is provided with a complete climate. The experimental plot of $200 \mathrm{~m} \times 75 \mathrm{~m}$ is fed by a well debiting $40 \mathrm{l} / \mathrm{s}$. The longi- tudinal slope is equal to $0.2 \%$. Water distribution is performed by PVC gated pipelines. The plot was cultivated with durum wheat (Karim variety) provided with the necessary inputs in a timely fashion.

\subsection{The Experimental Setup}

Three irrigation campaigns were carried out for evaluation purposes. To avoid interferences between neighboring blocks, these were installed $6 \mathrm{~m}$ from each other. Watering was triggered on the basis of soil moisture content. These allow the inference of the water holding capacity depletion level. Irrigation inflow was cut-off whenever the wave front reached the last $10 \mathrm{~m}$ from the downstream end of the furrow or the border.

The first irrigation campaign was intended to appraise the effect of the soil water depletion level (p) on furrow and border irrigation performance and on crop yield. To this end, two depletion levels were assessed: $60 \%$ and $90 \%$. These levels represent water deficits of 140 and $210 \mathrm{~mm}$, respectively. Table 1 shows that the adopted treatments differed in soil water depletion rate and irrigation system. Following Zairi et al. [13], we adopted a discharge of $1 \mathrm{l} / \mathrm{s}$ /furrow or per meter of border width.

Following the subdivision indicated in Table 1, irrigation evaluation was based upon:

- Comparing the effect of soil water depletion rate on irrigation performance for the same irrigation system. The compared strategies were taken separately in blocks 1 and 2. The furrow spacing and border width were the same for the two compared strategies,

- Comparing the different irrigation systems within the same block.

Analysis of the results recorded during the first campaign highlighted the primacy of furrow irrigation versus border irrigation in terms of hydraulic performance and crop yield. This result led to drop border irrigation during the second campaign, and focus only on furrow irrigation. Table 2 shows that the adopted treatments differed in unit inlet discharge and furrow spacing (S). The first campaign revealed that a depletion rate of $90 \%$ provides the best water conservation without significant crop yield reduction. This is why the treatments carried out during the second campaign dismissed the depletion rate of $60 \%$.

Table 1. Treatments applied during the first measurement campaign.

\begin{tabular}{clc}
\hline & \multicolumn{1}{c}{ Treatments } & p (\%) \\
\hline \multirow{3}{*}{ Block 1 } & Border: width $=6 \mathrm{~m}$ & \\
& Furrow: $\mathrm{S}=0.75 \mathrm{~m}$ & 60 \\
& Furrow: $\mathrm{S}=1.50 \mathrm{~m}$ & \\
Block 2 & Border: width $=6 \mathrm{~m}$ & \\
& Furrow: $\mathrm{S}=0.75 \mathrm{~m}$ & 90 \\
\hline
\end{tabular}

$\mathrm{S}$ = spacing between furrows. 
Table 2. Treatments adopted in the second campaign.

\begin{tabular}{cccc}
\hline Block & Treatments & S (cm) & Q (l/s/furrow) \\
\hline \multirow{3}{*}{ Block 1 } & F-150-Q & 150 & $\mathrm{Q}_{1}=1$ \\
& F-150-Q & 150 & $\mathrm{Q}_{2}=2$ \\
& F-150-Q & 150 & $\mathrm{Q}_{3}=3$ \\
Block 2 & F-75- $\mathrm{Q}_{1}$ & 75 & $\mathrm{Q}_{1}=1$ \\
& F-75- $\mathrm{Q}_{2}$ & 75 & $\mathrm{Q}_{2}=2$ \\
& F-75- $\mathrm{Q}_{3}$ & 75 & $\mathrm{Q}_{3}=3$ \\
\hline
\end{tabular}

In the second column, F refers to furrow irrigation; the numbers between hyphens refer to furrow spacing $(\mathrm{cm})$; $\mathrm{Q}_{\mathrm{k}}$ refers to unit inlet discharge; and the subscript refers to the corresponding treatment.

The third campaign was carried out with an inlet discharge of $2 \mathrm{l} / \mathrm{s} /$ furrow. As in the previous campaigns, the furrows were open at the distal end (free-flowing furrows). Three depletion rates were assessed: $30 \%, 60 \%$ and $90 \%$. The exhaustion rate of $30 \%$ corresponds to a low soil water deficit, and did not cause any cracking.

\subsection{Irrigation Monitoring and Evaluation}

Irrigation monitoring focused on 1) hydraulic measurements (advance and recession); 2) gravimetric measurements (soil moisture content) and 3) agronomic measurements (crop yield). Irrigation was evaluated using indicators: application efficiency (Ea) and distribution uniformity (DU), as defined by Merriam and Keller [18]. Two additional indicators were used: gross margin (GM) defined as the gross product minus the variable costs, and water value (WV). Indeed, the water mobilization is of prima facie importance in the decision making, particularly in a context of water shortages. The water value refers to the difference between the production value (PV) and all variable costs (VC) except those related to the consumed water (CW). Furthermore, it is interesting to note that WV is straightforwardly inferred from the relation:

$$
\mathrm{WV}=\frac{\mathrm{PV}-(\mathrm{VC}-\mathrm{CW})}{10 \times \mathrm{MAWD}}
$$

where MAWD refers to the mean applied water depth (mm).

\section{Results and Discussion}

\subsection{Results of the First Campaign}

A severe drought was registered during the first campaign. Indeed, over the cropping cycle (end of November to mid-June), only $85 \mathrm{~mm}$ of precipitation were recorded. This accounts for $28 \%$ of the mean inter-annual rainfall over the same period. Soil water measurements performed during sowing revealed about half of the water holding capacity. To homogenize water storage and enhance emergence, a water depth of $40 \mathrm{~mm}$ was supplied at that time. The application of such a small amount of water to a dry swelling soil was only possible by sprinkling. Apart from this initial water supply, all treatments were watered two (with $\mathrm{p}=90 \%$ ) or three (with $\mathrm{p}=60 \%$ ) times according to the soil water depletion rate.

Table 3 summarizes the applied water depths and hydraulic performance corresponding to the watering events at sowing and after sowing. Regardless of the soil water depletion rate, experimental results show that border irrigation required the highest mean water depths (MAWD) compared to furrow irrigation. The lowest application efficiencies were recorded for border irrigation. On the other hand, the mean water depths applied to borders (MAWD) were larger than water deficits (WD). This overrun was estimated to 35 and $70 \mathrm{~mm}$ for depletion rates of $90 \%$ and $60 \%$, respectively. It should be stressed that the furrow spacing of $150 \mathrm{~cm}$ required the lowest applied water depths (MAWD) compared to borders and furrows spaced $75 \mathrm{~cm}$. However, the moisture profiles should be considered with watchfulness because of potential lateral and vertical water losses induced by cracks. For the same irrigation system, Table 3 shows that mean applied water depths (MAWD) were quite similar, regardless of the imposed depletion rate. The effect of the depletion rate on the stored water depths (SWD) was more noticeable.

Prior to sowing, an initial water depth of $40 \mathrm{~mm}$ was applied by sprinkling to all these treatments. Table 3 shows that furrow irrigation produced the highest application efficiencies (Ea). In the overall, the distribution uniformity (DU) was fairly acceptable for all treatments. This result is ascribed to the high applied water depths (MAWD) compared to water deficit (WD). Table 4 summarizes crop yield (Ya) and the water use efficiency (WUE).

Despite the similar water depths stored during the cropping cycle, Table 4 shows that crop yields were higher for the depletion rate of $60 \%$ than for the depletion rate of $90 \%$. This result is due to the more severe water stress under a depletion rate of $90 \%$. This water stress is particularly harmful if it coincides with a sensitive stage of crop development. In the backdrop of a semi-arid climate, the adequate treatment is the one providing the best combination between crop yield, hydraulic efficiency and economic income. The results summarized in Tables 3 and 4 show that furrow irrigation implemented with a depletion rate of $90 \%$ produced the highest application efficiencies and required relatively moderate water application. At this level of soil desiccation, Table 5 shows adequate water use efficiencies and acceptable crop yields, particularly for furrows separated $150 \mathrm{~cm}$. These results show that furrow irrigation of wheat is an adequate alternative to border irrigation in the local swelling soils. 
Table 3. Soil moisture conditions before irrigation and hydraulic performance indicators.

\begin{tabular}{|c|c|c|c|c|c|}
\hline \multirow[b]{2}{*}{ Treatments } & \multicolumn{5}{|c|}{ Irrigation after sowing } \\
\hline & $\begin{array}{l}\text { WD } \\
(\mathrm{mm})\end{array}$ & $\begin{array}{l}\text { MAWD } \\
(\mathrm{mm})\end{array}$ & $\begin{array}{c}\mathrm{Ea} \\
(\%)\end{array}$ & $\begin{array}{l}\text { DU } \\
(\%)\end{array}$ & $\begin{array}{c}\text { SWD } \\
\text { (mm/irrigation) }\end{array}$ \\
\hline Border: $\mathrm{p}=90 \%$ & 210 & 245 & 49 & 93 & 120 \\
\hline Furrow: $\mathrm{S}=75 \mathrm{~cm}, \mathrm{p}=90 \%$ & 210 & 185 & 63 & 62 & 117 \\
\hline Furrow: $\mathrm{S}=150 \mathrm{~cm}, \mathrm{p}=90 \%$ & 210 & 150 & 65 & 95 & 98 \\
\hline Border: $\mathrm{p}=60 \%$ & 140 & 210 & 43 & 95 & 90 \\
\hline Furrow: $\mathrm{S}=75 \mathrm{~cm}, \mathrm{p}=60 \%$ & 140 & 170 & 46 & 87 & 78 \\
\hline Furrow: $\mathrm{S}=150 \mathrm{~cm}, \mathrm{p}=60 \%$ & 140 & 140 & 60 & 92 & 84 \\
\hline
\end{tabular}

Table 4. Crop yields and water use efficiency as function of applied and stored water depths.

\begin{tabular}{|c|c|c|c|c|c|}
\hline \multirow{2}{*}{ Treatments } & \multirow{2}{*}{$\begin{array}{c}\text { Ya } \\
\text { (qx/ha) }\end{array}$} & \multicolumn{2}{|c|}{ Total Water Depth (mm) } & \multirow{2}{*}{$\begin{array}{c}\mathrm{SC} \\
(\mathrm{mm})\end{array}$} & \multirow{2}{*}{$\begin{array}{r}\text { WUE } \\
\left(\mathrm{kg} / \mathrm{m}^{3}\right.\end{array}$} \\
\hline & & Applied & Stored & & \\
\hline Border: $\mathrm{p}=90 \%$ & 53.5 & 525 & 270 & 127 & 1.10 \\
\hline Furrow: $\mathrm{S}=75 \mathrm{~cm}, \mathrm{p}=90 \%$ & 53.0 & 410 & 275 & 103 & 1.14 \\
\hline Furrow: $\mathrm{S}=150 \mathrm{~cm}, \mathrm{p}=90 \%$ & 56.0 & 335 & 230 & 95 & 1.36 \\
\hline Border: $\mathrm{p}=60 \%$ & 59.0 & 675 & 305 & 60 & 1.31 \\
\hline Furrow: $\mathrm{S}=75 \mathrm{~cm}, \mathrm{p}=60 \%$ & 65.0 & 550 & 270 & 65 & 1.54 \\
\hline Furrow: $\mathrm{S}=150 \mathrm{~cm}, \mathrm{p}=60 \%$ & 60.5 & 455 & 285 & 82 & 1.33 \\
\hline
\end{tabular}

SC = soil water contribution.

Table 5. Comparison of irrigation hydraulic performance after sowing.

\begin{tabular}{ccccc}
\hline Treatment & AWD (mm/irrigation) & Ea (\%) & DU (\%) & MAWD (mm) \\
\hline F-75-Q ${ }_{1}$ & 220 & 50 & 70 & 560 \\
F-75-Q 2 & 220 & 50 & 60 & 560 \\
F-75-Q 23 & 250 & 50 & 85 & 620 \\
F-150-Q & 135 & 85 & 65 & 390 \\
F-150-Q Q & 150 & 75 & 75 & 420 \\
F-150-Q & 170 & 55 & 70 & 460 \\
\hline
\end{tabular}

AWD: applied water depth (mm/irrigation).

These findings corroborate those of Zairi et al. [19] obtained in the Medjerda lower valley. It should be highlighted that the above results are dependent on the used inlet discharge $(1 \mathrm{l} / \mathrm{s})$. The second measurement campaign clarifies the influence of this parameter.

\subsection{Results of the Second Campaign}

An outstanding drought was registered during the second campaign too. Cumulative precipitation recorded during the cropping cycle was $165 \mathrm{~mm}$. This amount accounts for $55 \%$ of the average inter-annual rainfall over the same period. The gravimetric moisture sampling at sowing revealed that the water holding capacity was filled up to $25 \%$. All treatments received an initial water supply of $120 \mathrm{~mm}$ to ease crop emergence and ensure homogenization of soil conditions. Apart from this water supply, all treatments were irrigated twice from heading to grain filling. Table 5 summarizes irrigation performance for the applied treatments. This campaign upholds the afore- mentioned results inasmuch as the highest water depths and the lowest application efficiencies were associated to a furrow spacing of $75 \mathrm{~cm}$. For the same inlet discharge, the difference between the mean applied water depth (MAWD) ranged from $140 \mathrm{~mm}\left(\mathrm{Q}_{2}=2 \mathrm{l} / \mathrm{s} /\right.$ furrow) to $170 \mathrm{~mm}\left(\mathrm{Q}_{1}=1 \mathrm{l} / \mathrm{s} /\right.$ furrow $)$.

Table 6 shows that the differences in crop yield (Ya) are not proportional to the difference between the mean applied water depths (MAWD). Subsequently, tangible water savings can be made without noteworthy crop yield reduction. Thus, the use of a furrow spacing of 150 $\mathrm{cm}$ for wheat irrigation in cracked soils seems to be appropriate in this context.

As expected, Figure 1 shows that the fastest wavefront advance matched the largest inlet discharge. For a $150 \mathrm{~cm}$ spacing between furrows, Table 5 shows that the application efficiency decreased as the inlet discharge increased. Table 5 also shows that application efficiency dropped by $30 \%$ when the inlet discharge rose from 1 to $3 \mathrm{l} / \mathrm{s} /$ furrow, causing a gap of $70 \mathrm{~mm}$ between the mean 
applied water depths (MAWD). Amazingly, for the same furrow spacing, Table 6 shows that the highest mean applied water depth (MAWD) induced the lowest crop yield. This result is ascribed to the corresponding low application efficiency. Given the small difference between the crop yields generated by the two lowest inflows ( 1 and 2 l/s/furrow), the choice of the inlet discharge must be rational. Figure 1 shows that the choice of the pair $\left(\mathrm{Q}_{2}=2 \mathrm{l} / \mathrm{s} /\right.$ furrow, $\left.\mathrm{S}=150 \mathrm{~cm}\right)$ reduced the irrigation time by $300 \mathrm{~min}$. Based on crop yield, applica-

Table 6. Crop yield, cumulative supplied water depth and water use efficiency.

\begin{tabular}{cccc}
\hline Treatments & Ya (qx/ha) & MAWD $(\mathrm{mm})$ & WUE $\left(\mathrm{kg} / \mathrm{m}^{3}\right)$ \\
\hline F-75-Q & 49 & 560 & 1.07 \\
F-75-Q & 52 & 560 & 0.98 \\
F-75-Q & 58 & 620 & 0.82 \\
F-150-Q & 55 & 390 & 1.18 \\
F-150-Q 2 & 57 & 420 & 1.12 \\
F-150-Q & 47 & 460 & 1.07 \\
\hline
\end{tabular}

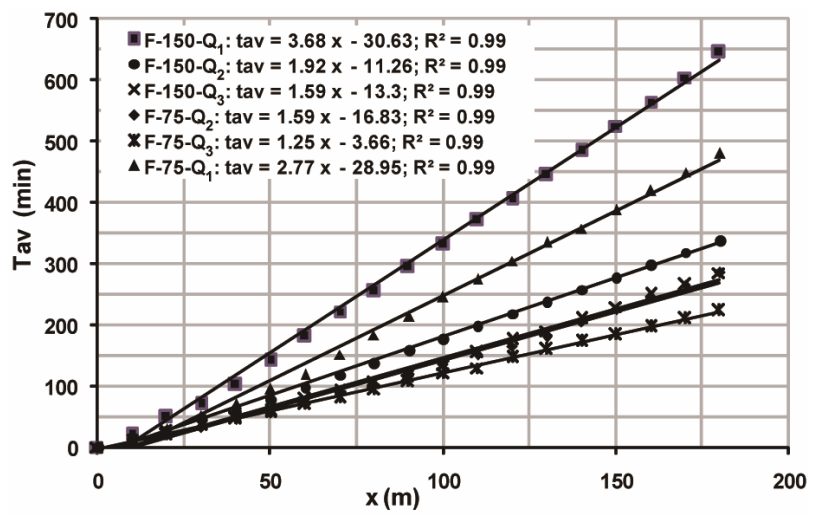

Figure 1. Advance curves corresponding to a soil water depletion of $90 \%$. tion efficiency and irrigation time, one is led to prioritize the inlet discharge of $2 \mathrm{l} / \mathrm{s} /$ furrow at the expense of 1 1/s/furrow. Water use efficiency (WUE) reported in Table 6 advocates for furrow irrigation with spacing of 150 $\mathrm{cm}$.

Gross margins (GM) and water values (WV) reported in Table 7 corroborate the effectiveness of the discharge of $2 \mathrm{l} / \mathrm{s} /$ furrow. Note that the pair $\left(\mathrm{Q}_{2}=2 \mathrm{l} / \mathrm{s} /\right.$ furrow, $\mathrm{S}=$ $150 \mathrm{~cm}$ ) yielded the highest gross margin and water value. By cons, the pair $\left(\mathrm{Q}_{1}=1 \mathrm{l} / \mathrm{s} /\right.$ furrow, $\left.\mathrm{S}=75 \mathrm{~cm}\right)$ produced the lowest gross margin and water value. It should be borne in mind that variable costs (VC) include seed, water, labor, fertilizers, mechanization and weeding costs.

In the foregoing, it has been assumed that the cost of the other variables (COV) is constant regardless of the adopted treatment. The cost of water $(\mathrm{CW})$ is calculated in pro rata with the cumulative distributed water volumes. It should be stressed that the pair $\left(\mathrm{Q}_{2}=2 \mathrm{l} / \mathrm{s} /\right.$ furrow, $\mathrm{S}=$ $150 \mathrm{~cm}$ ) required a relatively low labor cost (LC) and provided a quite good productivity value (PV). Furthermore, it is interesting to note that GM is equal to:

$$
\mathrm{GM}=\mathrm{PV}-(\mathrm{LC}+\mathrm{CW}+\mathrm{COV})
$$

\subsection{Results of the Third Campaign}

For the third consecutive time, a relevant drought was registered during this campaign. Incidentally, only 55 $\mathrm{mm}$ of precipitation were recorded during the cropping cycle, which accounts for $20 \%$ of the inter-annual average over the same period. Soil moisture measurements at sowing revealed that the holding capacity was filled up to $55 \%$. All treatments received a water supply of $100 \mathrm{~mm}$ at sowing in order to foster crop emergence and homogenize initial conditions. Table 8 shows that the number of irrigation events (NI) depended on the soil water exhaustion rate (p).

Table 7. Gross margin and water value of the various treatments.

\begin{tabular}{|c|c|c|c|c|c|c|c|}
\hline Treatments & $\begin{array}{c}\text { PV } \\
\text { (TD/ha) }\end{array}$ & LC(TD/ha) & $\begin{array}{c}\text { CW } \\
\text { (TD/ha) }\end{array}$ & $\begin{array}{c}\text { COV } \\
\text { (TD/ha) }\end{array}$ & $\begin{array}{c}\text { VC } \\
\text { (TD/ha) }\end{array}$ & $\begin{array}{c}\text { GM } \\
\text { (TD/ha) }\end{array}$ & $\begin{array}{c}\text { WV } \\
\left(\mathrm{TD} / \mathrm{m}^{3}\right)\end{array}$ \\
\hline $\mathrm{F}-75-\mathrm{Q}_{1}$ & 2744 & 335.64 & 672 & 1157 & 2164.64 & 579.36 & 0.22 \\
\hline $\mathrm{F}-75-\mathrm{Q}_{3}$ & 3248 & 178.93 & 744 & 1157 & 2079.93 & 1168.07 & 0.30 \\
\hline $\mathrm{F}-150-\mathrm{Q}_{1}$ & 3080 & 197.91 & 468 & 1157 & 1822.91 & 1257.09 & 0.44 \\
\hline $\mathrm{F}-150-\mathrm{Q}_{2}$ & 3192 & 127.08 & 504 & 1157 & 1788.08 & 1403.92 & 0.45 \\
\hline $\mathrm{F}-150-\mathrm{Q}_{3}$ & 2632 & 106.48 & 552 & 1157 & 1815.48 & 816.52 & 0.29 \\
\hline
\end{tabular}

1 Tunisian Dinar $($ 1TD) $=0.629 \$$ at the date of November 19, 2012.

Table 8. Hydraulic performance of irrigations after sowing.

\begin{tabular}{cccccc}
\hline $\mathrm{p}$ & WD $(\mathrm{mm})$ & NI & MAWD $(\mathrm{mm})$ & Ea (\%) & DU (\%) \\
\hline $\mathrm{p}=30 \%$ & 70 & 5 & 65 & 75 & 70 \\
$\mathrm{p}=60 \%$ & 140 & 3 & 110 & 65 & 80 \\
$\mathrm{p}=90 \%$ & 210 & 2 & 145 & 60 & 70 \\
\hline
\end{tabular}


As expected, these results show that the soil water deficit (WD) and the mean applied water depths (MAWD) increased gradually as the soil became dry. Contrariwise, the number of required irrigation events and the application efficiency decreased as the soil water exhaustion rate increased. This behavior is due to the slow advance velocities in dry furrows, as shown in Figure 2. It should be underlined that the increase of the number of irrigation events induced less soil cracking and hence lesser water losses. Regarding distribution uniformity (DU), Table 8 shows that the trend was irregular. The treatment corresponding to a soil water depletion level of $30 \%$ produced acceptable distribution uniformity and the highest application efficiency. Since the mean applied water depths (MAWD) were lower than the soil water deficits (WD), one is led to conclude that none of the aforementioned treatments was capable to induce deep percolation. Such an irrigation stewardship is not sustainable, as it favors gradual accumulation of salts within the root-zone. However, this assertion should be nuanced inasmuch as cracks foster deep percolation even if the soil water content is lower than field capacity.

Figures $\mathbf{1}$ and $\mathbf{2}$ indicate that wave-front advance along the furrows was quasi-linear. This result corrobo- rates that of Waller and Wallender [12] for borders. Table 9 summarizes crop yield, mean applied water depth (MAWD), total stored water depth (TSWD), soil water contribution (SC), actual evapotranspiration (ETR) and water use efficiency (WUE) for the various treatments.

Table 9 shows that crop yields (Ya) dwindled as the mean applied water depth (MAWD) and the total stored water depth (TSWD) decreased. The difference between crop yields generated by soil water depletion levels of $30 \%$ and 60\% was relatively small. Table 9 also shows that the three treatments had comparable water use efficiencies (WUE), which exclude a priori this parameter from the comparison criteria. Furthermore, Table 10 indicates that the soil water depletion level of $30 \%$ generated the highest gross margin and better leveraged irrigation water. Conversely, the soil water depletion level of $90 \%$ generated the lowest gross margin.

It can be inferred that the soil water depletion level of $30 \%$ produced the best results from the hydraulic, agronomic and economic standpoints. However, it is unlikely that the farmer is able to irrigate his plot when the soil water depletion levels are very low, given the imperatives of water availability and labor cost.

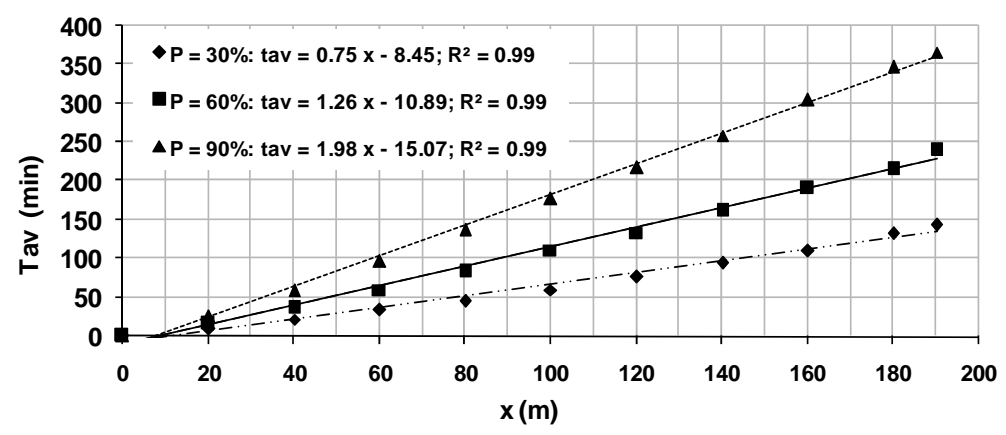

Figure 2. Furrow irrigation advance curves for the different treatments.

Table 9. Crop indicators for the different treatments.

\begin{tabular}{ccccccc}
\hline Depletion & Ya (qx/ha) & $\begin{array}{c}\text { MAWD } \\
(\mathrm{mm})\end{array}$ & TSWD (mm) & $\begin{array}{c}\text { SC } \\
(\mathrm{mm})\end{array}$ & $\begin{array}{c}\text { ETR } \\
(\mathrm{mm})\end{array}$ & $\begin{array}{c}\text { WUE } \\
\left(\mathrm{kg} / \mathrm{m}^{3}\right)\end{array}$ \\
\hline $\mathrm{p}=30 \%$ & 58 & 430 & 320 & 30 & 405 & 1.43 \\
$\mathrm{p}=60 \%$ & 54 & 425 & 280 & 75 & 410 & 1.32 \\
$\mathrm{p}=90 \%$ & 51 & 390 & 245 & 40 & 340 & 1.50 \\
\hline
\end{tabular}

Table 10. Gross margin and water value for the adopted treatments $(S=150 \mathrm{~cm})$.

\begin{tabular}{rccccccc}
\hline Depletion & $\begin{array}{c}\mathrm{PV} \\
(\mathrm{DT} / \mathrm{ha})\end{array}$ & $\begin{array}{c}\mathrm{LC} \\
(\mathrm{DT} / \mathrm{ha})\end{array}$ & $\begin{array}{c}\mathrm{CW} \\
(\mathrm{DT} / \mathrm{ha})\end{array}$ & $\begin{array}{c}\mathrm{COV} \\
(\mathrm{DT} / \mathrm{ha})\end{array}$ & $\begin{array}{c}\text { VC } \\
(\mathrm{DT} / \mathrm{ha})\end{array}$ & $\begin{array}{c}\text { GM } \\
(\mathrm{DT} / \mathrm{ha})\end{array}$ & $\begin{array}{c}\text { WV } \\
\left(\mathrm{DT} / \mathrm{m}^{3}\right)\end{array}$ \\
\hline $\mathrm{p}=30 \%$ & 3248 & 185.76 & 516 & 1157 & 1858.76 & 1389.23 & 0.44 \\
$\mathrm{p}=60 \%$ & 3024 & 182.63 & 510 & 1157 & 1849.63 & 1174.36 & 0.39 \\
$\mathrm{p}=90 \%$ & 2856 & 167.36 & 468 & 1157 & 1792.36 & 1063.63 & 0.39 \\
\hline
\end{tabular}

1 Tunisian Dinar (1TD) = 0.629 \$ at the date of November 19, 2012. 


\section{Conclusion}

Cereal crops are customarily fed by border, basin or sprinkle irrigation. For clayey swelling soils, irrigation is carried out in presence of cracks. Experimental results show that border irrigation generates noteworthy water losses. The evaluation of wheat irrigation by furrows was undertaken although this system is rarely used for irrigating dense crops. To this end, the evaluation was based upon hydraulic, agronomic and economic criteria. The field trials with open furrows of $200 \mathrm{~m}$ long and $150 \mathrm{~cm}$ apart generated conclusive results, particularly with an inlet discharge of $2 \mathrm{l} / \mathrm{s}$ and a soil water depletion level of $90 \%$. Indeed, this irrigation strategy has led to an application efficiency of $60 \%$, a distribution uniformity of $70 \%$, a cumulative water supply throughout the vegetative cycle of $390 \mathrm{~mm}$, a yield of $51 \mathrm{qx} / \mathrm{ha}$, a water consumption efficiency of $1.47 \mathrm{~kg} / \mathrm{m}^{3}$, a gross margin of $1064 \mathrm{TD} / \mathrm{ha}$ and a water value of $0.39 \mathrm{TD} / \mathrm{m}^{3}$. In the local swelling soils, experimental results showed that wheat irrigation by furrows is more adequate than border irrigation form the hydraulic, agronomic and economic standpoints.

\section{Acknowledgements}

The authors are thankful to the INRGREF for the valuable support of this research.

\section{REFERENCES}

[1] M. Abu-Zeid and A. Hamdy, "Water Vision for the Twenty-First Century in the Arab World,” World Water Council, International Policy Think Tank, Arab Countries Vision Consultations, Marseille, 2002.

[2] W. R. Walker and G. V. Skogerboe, "Surface Irrigation: Theory and Practice,” Prentice Hall, Upper Saddle River, 1987, p. 386.

[3] M. N. Orang, J. S. Matyac and R. L. Snyder, "Survey of irrigation Methods in California in 2001," Journal of Irrigation and Drainage Engineering, Vol. 134, No. 1, 2008, pp. 96-100. doi:10.1061/(ASCE)0733-9437(2008)134:1(96)

[4] Gouvernement d’Espagne, “Anuario de Estadística Agroalimentaria,” Ministerio de Agricultura, Pesca y Alimentación, Gobierno de España, Madrid, 2006. www.mapa.es

[5] “Aquastat, L’Irrigation en Afrique en Chiffres,” La Tunisie-Enquête AQUASTAT 2005, p.12.

[6] H. H. Gerke, "By-Pass Flow in Soil,” In: J. Glinski, J. Horabik and J. Lipiec, Eds., Encyclopedia of Agro-Physics, Springer, Dordrecht, 2011, pp. 100-107.

[7] D. Hillel, "Environmental Soil Physics,” Academic Press,
London, 1998, p. 771.

[8] R. L. Donahue, R. W. Miller and J. C. Schickluna, “An Introduction to Soils and Plant Growth,” Prentice Hall, Upper Saddle River, 1977.

[9] M. H. Ali, "Fundamentals of Irrigation and on Farm Water Management,” Vol. 1, Springer, New York, 2010, p. 556. doi:10.1007/978-1-4419-6335-2

[10] Y. M. Cabidoche and B. Ney, "Fonctionnement Hydrique des Sols à Argiles Gonflantes Cultivés. II.-Analyse Expérimentale des Fonctionnements Hydriques Associés à Deux États Structuraux en Vertisol Irrigué,” Agronomie, Vol. 7, No. 4, 1987, pp. 257-270. doi:10.1051/agro:19870405

[11] C. W. Liu, S. W. Cheng, W. S. Yu and S. K. Chen, "Water Infiltration Rate in Cracked Paddy Soil," Geoderma, Vol. 117, No. 1-2, 2003, pp. 169-181. doi:10.1016/S0016-7061(03)00165-4

[12] P. M. Waller and W. W. Wallender, "Infiltration in Surface Irrigated Swelling Soils,” Irrigation and Drainage Systems, Vol. 5, No. 3, 1991, pp. 249-266. doi:10.1007/BF01112502

[13] A. Zairi, A. Slatni, J. C. Mailhol and H. Achour, "Surface Irrigation Efficiency in Cracking Soils as Influenced by Water Restriction,” In: L. S. Pereira and J. W. Gowing, Eds., Water and the Environment-Innovation Issues in Irrigation and Drainage, CRC Press, Boca Raton, 1998, pp. 120-130.

[14] A. Zairi,A. Slatni, H. El Amami, L. S. Pereaira, P. Rodrigues, A. Derouiche, H. Achour and J. L. Teixeira, “Stratégies D’Irrigation des Céreales en Fonction des Disponibilités D’Eau et de la Technique D’Application Dans le Contexte Tunisien. Séminaire Euro-Méditerranéen sur la Maîtrise de L’Irrigation et du Drainage Pour une Gestion Durable des Périmètres Irrigués Méditerranéens,” Rabat, 1999, pp. 27-29.

[15] A. J. Clemmens and A. R. Dedrick, "Irrigation Techniques and Evaluations,” In: K. K. Tanji and B. Yaron, Eds., Advanced Series in Agricultural Sciences, SpringerVerlag, Berlin, 1994, pp. 64-103.

[16] N. Zapata, E. Playán and J. M. Faci, “Elevation and Infiltration on a Level Basin: II. Impact on Soil Water and Corn Yield,” Irrigation science, Vol. 19, No. 4, 2000, pp. 165-173. doi:10.1007/PL00006711

[17] E. Playán, A. Slatni, R. Castillo and J. M. A. Faci, “Case Study for Irrigation Modernisation: II. Scenario Analysis,” Agricultural Water Management, Vol. 42, No. 3, 2000, pp. 335-354. doi:10.1016/S0378-3774(99)00051-7

[18] J. L. Merriam and J. Keller, "Farm Irrigation System Evaluation, A Guide for Management," Utah State University, Logan, 1978, p. 271.

[19] A. Zairi, H. Achour and A. Slatni, "Impact de la Restriction de L'eau sur la Qualité de L’irrigation de Surface sur un sol Fendillant,” Rapport de Recherche, 1997, p. 32. 